\title{
Development and characterization of Pleurotus ostreatus mushroom- wheat bread
}

C. Losoya-Sifuentes ${ }^{a}$, L. S. Simões ${ }^{b}$, M. Cruz ${ }^{c *}$, R.M. Rodriguez-Jasso ${ }^{a}$, A. LoredoTreviño $^{a}$, J. A. Teixeira ${ }^{b}$, C. Nobre ${ }^{b}$, R. Belmares ${ }^{a *}$

a Department of Food Research, Faculty of Chemical Sciences, Autonomous University of Coahuila, Saltillo, Mexico. Blvd. V. Carranza e Ing. José Cárdenas s/n Col. República C.P. 25280, Saltillo, Coahuila, México.

${ }^{\mathrm{b}}$ CEB - Centre of Biological Engineering, University of Minho, Campus de Gualtar, 4710-057, Braga, Portugal

${ }^{c}$ Department of Food Science and Technology, Antonio Narro Autonomous Agrarian University, Saltillo, Mexico. Calzada Antonio Narro, N 1923 Col. Buena Vista C.P. 25315, Buenaventura, Coahuila, México

*Corresponding author: ruthbelmares@uadec.edu.mx (R. Belmares).

Department of Food Research, Faculty of Chemical Sciences, Autonomous University of Coahuila, Saltillo, Mexico. Blvd. V. Carranza e Ing. José Cárdenas s/n Col. República C.P. 25280, Saltillo, Coahuila, México.

*Corresponding author: myke13_80@hotmail.com (M. Cruz).

This article has been accepted for publication and undergone full peer review but has not been through the copyediting, typesetting, pagination and proofreading process, which may lead to differences between this version and the Version of Record. Please cite this article as doi: 10.1002/star.202100126.

This article is protected by copyright. All rights reserved. 
Department of Food Science and Technology, Antonio Narro Autonomous Agrarian University, Saltillo, Mexico. Calzada Antonio Narro, N 1923 Col. Buena Vista C.P. 25315, Buenaventura, Coahuila, México.

\begin{abstract}
The Pleurotus ostreatus mushroom is a source of high nutritional value and bioactive compounds such as $\beta$-glucans, with immunomodulatory, hypoglycemic and prebiotic activity. The aim of this work was to developed a bread with $P$. ostreatus powder (POP) to increase its nutritional value and reduce its glycemic index.

Four formulations were proposed substituting $5,10,15$ and $20 \%$ of wheat flour (w/w) for POP in the bread and their physical characteristics and nutritional were evaluated. In addition to determining the glycemic index and the in vitro digestion of starch in the proposed formulations. Results shown that with the addition of POP the specific volume of the bread decreased, and it became darker. The nutritional value of the bread was enriched, since the content on proteins, fiber and minerals increased. The results of in vitro simulated gastrointestinal digestion demonstrated that bread supplemented with POP showed more optimal starch digestibility with slower digestion rate, lower eGI and RDS contents, which could bring health benefits to humans. These findings suggest that the mushroom powder is an excellent alternative to produce bread with improved nutritional quality and decreased glycemic index.
\end{abstract}

Keywords: edible mushroom, glycemic index, Pleurotus ostreatus, wheat bread 


\section{Introduction}

Bread is one of the most consumed food worldwide. Wheat flour (Triticum aestivum), water, yeast or other leavening agents and salt have been used as basic ingredients since ancient times. The product of the milling of the wheat grain is a white flour rich in starch and proteins of gluten. Unfortunately, many of the important nutrients such as protein, dietary fiber, B vitamins, and minerals are also removed if all parts of the grain are not preserved [1,2]. White bread is a food rich in starch and low in dietary fiber, is associated with a high glycemic index (GI) that promotes a rapid increase in blood glucose [3]. Eating high GI foods can affect human health, promoting the development of metabolic disorders and diseases, such as diabetes and cardiovascular disease [4]. Nowadays, adoption of a healthy lifestyle is increasing, and breads containing whole grains or other functional ingredients have positioned themselves on the market. Therefore, new ingredients are necessary to develop products that can compete with breads made with refined flours, with higher nutritional value and additional functional properties [2].

Recent research on edible mushrooms indicates that their bioactive compounds with nutraceutical and functional properties have multiple beneficial effects on human health, in addition to their high nutritional value and appreciated organoleptic qualities $[5,6]$. Likewise, consumption in their natural form in common dishes, edible mushrooms have been incorporated into food formulations to obtain new functional foods [7] .

The edible mushroom Pleurotus ostreatus cultivated worldwide [8], known as oyster mushroom, is an important source of amino acids, proteins, unsaturated fatty acids, vitamins, fiber and has low energy [9]. $P$. ostreatus has been grown on lignocellulosic substrates, which are by-products of the food industry (e.g., grain 
residues) and a relatively inexpensive material [10]. It receives a great interest from the scientific community due to its anti-inflammatory properties (e.g., curative and immunostimulatory effects) [11], prebiotic potential (e.g., stimulating the growth of some beneficial bacteria in the colon) [12] and hypoglycemic activity $[13,14]$ In addition it contains a large amount of ergotioneine and polyphenols with antioxidant activities [15].

The incorporation of edible mushrooms of the genus Pleurotus spp in foods in different forms with different purposes has been reported. In meat products, the incorporation of $P$. ostreatus, at an adequate level, has effect on the organoleptic characteristics of these products. This mushroom promotes the oxidation of lipids and proteins of the meat and generate compounds that improve the flavor; however, changes in color and texture also occur. The addition of mushrooms to these foods should be studied further to find the optimal amount [16]. In dairy products, there has been an increase in nutritional quality, especially changes in the content of protein and dietary fiber, in addition to providing functional activity $[17,18]$. There is research focused on fortifying starch-rich cereal products that have a favorable effect on lowering the glycemic index and increasing dietary fiber.

$[19,20]$.

According to the Mexican Standard NMX-V-022-1972, aguamiel is the "juice obtained by previously scraping the central cavity of the maguey pulquero". This agave sap is a sweet liquid, hence its name in Spanish - "agua" which means water and "miel" which means honey. By easily undergoing natural fermentation, it becomes a non-distilled alcoholic beverage called pulque, which is a drink consumed in Mexico since prehispanic times [21,22]. Aguamiel is rich in sugars such as sucrose, fructose and glucose, as well as composed of sugars such as glucose, 
sucrose and fructose, fructans, gums, proteins, minerals, vitamins, amino acids, saponins, phenolic compounds and fructo-oligosaccharides (FOS) known for their prebiotic effects [23-25]. Due to these characteristics, in this work it was used as an ingredient in bread formulations. Aguamiel may become a novel alternative to sucrose commonly used in confectionery to promote yeast fermentation and increase the specific volume of wheat bread. [26].

The present research aimed to enrich wheat bread with powder of edible mushroom $P$. ostreatus (POP) to increase the nutritional value of the final bread and reduce its glycemic index.

\section{Experimental Section}

\subsection{POP preparation}

The POP was prepared and provided by the Plant Breeding Department and the Food Technology Department of the Autonomous Agrarian University Antonio Narro (UAAAN), located in Saltillo, Mexico. P. ostreatus mushroom were grown in sorghum and wheat straw in an incubator (ShelLbab), at $28{ }^{\circ} \mathrm{C}$ and in dark conditions. Ripe mushrooms were manually harvested after 40 days, dried in an electric oven at 60 ${ }^{\circ} \mathrm{C}$ for $48 \mathrm{~h}$ and grounded (mill Pulvex mini 100). The resulting powder was filtered through a $45-$ mesh $(350 \mu \mathrm{m})$ sieve to obtain the Pleurotus ostreatus powder (POP) (sieve Tyler RO-TAP RX-29).

\subsection{Bread formulations}

The control bread $(\mathrm{CB})$ was formulated with the following ingredients: wheat flour $(160 \mathrm{~g})$, yeast $(4 \mathrm{~g})$, whole milk $(75 \mathrm{ml})$, aguamiel $(10 \mathrm{ml})$, canola oil $(12 \mathrm{ml})$, salt (3 g) and water (35 ml). 5, 10, 15 and $20 \%$ of wheat flour (w/w) was replaced with POP 
and these bread with Pleurotus ostreatus (BPO) were named as $\mathrm{BPO}_{5}, \mathrm{BPO}_{10}$, $\mathrm{BPO}_{15}, \mathrm{BPO}_{20}$, respectively. The ingredients were thoroughly mixed with the help of an electric mixer (Black \& Decker MX900). The dough was fermented for $1 \mathrm{~h}$ at room temperature $\left(25^{\circ} \mathrm{C}\right)$. The dough was weighed and divided into equal portions, then, it was placed in baking pans, fermented again for 30 min and finally baked for 22 min at $150{ }^{\circ} \mathrm{C}$, in an electric convection oven (San Son, HCX PLUS 3). Once baked, the breads were allowed to cool for $1 \mathrm{~h}$ at room temperature $\left(25^{\circ} \mathrm{C}\right)$ and stored in polyethylene bags until further analysis. All breads were prepared at least in triplicate.

\subsection{Chemical composition of POP and breads}

Moisture, crude fat, crude protein, crude fiber and ash content were determined by AOAC official method [27]. A conversion factor of 4.38 was used to convert $\% \mathrm{~N}$ to $\%$ crude protein in the POP (presence of non-protein nitrogen in mushrooms) sample and for bread the conversion factor was 6.25 [28,29]. Carbohydrate contents were calculated by difference method $(100-$ (protein + lipids content + ash content + moisture content) and energy was determined by Equation 1 [30]. All these analyses were performed in triplicate.

Energy $(k c a l)=4 \times(g$ protein $+g$ carbohydrate $)+(9 \times g$ lipid $)$

\subsection{Physical properties of bread}

\subsubsection{Specific volume}


Specific volume of the bread was measured by the seed displacement method according to the AACC 10-05.01 method [31]. The bread volume and specific volume was evaluated using Equation 2 and 3, as following:

Volume $\left(\mathrm{cm}^{3}\right)=\pi \times$ radius of the cylinder $(\mathrm{cm})^{2} \times$ displacement distance $(\mathrm{cm})$

(2)

Specific volume $\left(\mathrm{cm}^{3} \mathrm{~g}^{-1}\right)=\frac{\text { volume }\left(\mathrm{cm}^{3}\right)}{\text { weight of unit bread }(\mathrm{g})}$

\subsubsection{Color}

The bread crumb color was measured according to CIE-L*a*b color space representation using a digital colorimeter (Colorimeter 3nH NR20XE).

\subsection{Measurement of total starch content}

For the determination of total starch bread, the Total Starch Assay Kit (AA/AMG) from Megazyme (K-TSTA, Ireland) was used. Bread sample (100 mg) was washed with an aqueous ethanol solution $(80 \% \mathrm{v} / \mathrm{v}, 5 \mathrm{~mL})$ and incubated at $80{ }^{\circ} \mathrm{C}$ for $5 \mathrm{~min}$. Subsequently, another $5 \mathrm{ml}$ of $80 \% \mathrm{v} / \mathrm{v}$ aqueous ethanol solution was added, and the samples were centrifuged (EBA 20, Hettich, Germany) at $1800 \times \mathrm{g}$ for $10 \mathrm{~min}$. The supernatant was discarded, and $10 \mathrm{ml}$ of $80 \% \mathrm{v} / \mathrm{v}$ aqueous ethanol solution was added to the pellet and centrifuged at the same conditions before. Then, $2 \mathrm{ml}$ of $\mathrm{KOH} 2 \mathrm{~mol} \mathrm{~L}^{-1}$ was added to the resulting solution and stirred on cold water $\left(4^{\circ} \mathrm{C}\right)$ for $20 \mathrm{~min}$. This process facilitated to resistant starch hydrolyzes. Sample was neutralized with $8 \mathrm{ml} 1.2 \mathrm{~mol} \mathrm{~L}^{-1}$ sodium acetate buffer solution at $\mathrm{pH} 3.8$. The enzymes thermostable $\alpha$-amylase $(3000 \mathrm{U} \mathrm{mL}-1$ on Ceralpha reagent at $\mathrm{pH} 6.5$ and $40{ }^{\circ} \mathrm{C}$ or $1600 \mathrm{U} \mathrm{mL}^{-1}$ on Ceralpha reagent at $\mathrm{pH} 5.0$ and $40{ }^{\circ} \mathrm{C}$, Megazyme, Ireland) and of amyloglucosidase $\left(3300 \mathrm{U} \mathrm{mL}^{-1}\right.$ on soluble starch or $200 \mathrm{U} \mathrm{mL}^{-1}$ on $\mathrm{p}$ - 
nitrophenyl $\beta$-maltoside at $\mathrm{pH} 4.5$ and $40{ }^{\circ} \mathrm{C}$, Megazyme, Ireland) were added and incubated at $50{ }^{\circ} \mathrm{C}$ for $30 \mathrm{~min}$. The total volume was adjusted to $100 \mathrm{~mL}$ with distilled water and centrifuged at the same conditions before. Afterwards, a resulting solution sample $(36.5 \mu \mathrm{L})$ was added to glucose oxidase-peroxidase (GOPOD) solution (333.5 $\mu \mathrm{L})$, distilled water $(666.5 \mu \mathrm{L})$ and incubated at $50{ }^{\circ} \mathrm{C}$ for $20 \mathrm{~min}$. The absorbance was measured at wavelength $510 \mathrm{~nm}$ (Synergy HT, Vermont, USA) and the percentage of D-glucose in the initial samples $(100 \mathrm{mg})$ was determined. The total starch was performed by multiplying the percentage of D-glucose by the conversion factor (162/180), which represents anhydrous D-glucose and free Dglucose molecular weight, respectively. The starch available values were normalized with the percentage of total starch hydrolyzed.

\subsection{Gastrointestinal digestion}

\subsubsection{Static in vitro simulation of gastrointestinal food digestion}

To evaluate starch hydrolysis of all the bread formulations $\left(\mathrm{CB}, \mathrm{BPO}_{5}, \mathrm{BPO}_{10}\right.$, $\left.\mathrm{BPO}_{15}, \mathrm{BPO}_{20}\right)$ an static in vitro simulation of gastrointestinal food digestion was carried out following the standardized protocol INFOGEST [32] to mimic mouth, stomach, and small intestine conditions. Figure 1 summarizes the process of starch hydrolysis. Simulated digestion fluids (i.e., Simulated Salivary Fluid (SSF: KCI 15.1 mmol L ${ }^{-1}, \mathrm{KH}_{2} \mathrm{PO}_{4} 3.7 \mathrm{mmol} \mathrm{L}^{-1}, \mathrm{NaHCO}_{3} 13.6 \mathrm{mmol} \mathrm{L}^{-1}, \mathrm{MgCl}_{2}\left(\mathrm{H}_{2} \mathrm{O}\right)_{6} 0.15 \mathrm{mmol} \mathrm{L}^{-1}$, $\left(\mathrm{NH}_{4}\right)_{2} \mathrm{CO}_{3} 0.06 \mathrm{mmol} \mathrm{L}^{-1}, \mathrm{HCl} 1.1 \mathrm{mmol} \mathrm{L}^{-1}$ ); Simulated Gastric Fluid (SGF: KCl 6.9 mmol L L ${ }^{-1} \mathrm{KH}_{2} \mathrm{PO}_{4} 0.9 \mathrm{mmol} \mathrm{L}{ }^{-1}, \mathrm{NaHCO}_{3} 25 \mathrm{mmol} \mathrm{L}{ }^{-1}, \mathrm{NaCl} 47.2 \mathrm{mmol} \mathrm{L} \mathrm{L}^{-1}$, $\mathrm{MgCl}_{2}\left(\mathrm{H}_{2} \mathrm{O}\right)_{6} 0.1 \mathrm{mmol} \mathrm{L}^{-1}$, (NH4)2CO3 $\left.0.5 \mathrm{mmol} \mathrm{L}^{-1}, \mathrm{HCl} 15.6 \mathrm{mmol} \mathrm{L}{ }^{-1}\right)$; Simulated Intestinal Fluid (SIF: KCl $6.8 \mathrm{mmol} \mathrm{L}^{-1}, \mathrm{KH}_{2} \mathrm{PO}_{4} 0.8 \mathrm{mmol} \mathrm{L}^{-1}, \mathrm{NaHCO}_{3} 85 \mathrm{mmol} \mathrm{L}^{-1}$, $\left.\mathrm{NaCl} 38.4 \mathrm{mmol} \mathrm{L}^{-1}, \mathrm{MgCl}_{2}\left(\mathrm{H}_{2} \mathrm{O}\right)_{6} 0.33 \mathrm{mmol} \mathrm{L}^{-1}, \mathrm{HCl} 8.4 \mathrm{mmol} \mathrm{L}^{-1}\right)$ ) were prepared 
for a volume of $400 \mathrm{~mL}$ with purified water (1.25 x concentration). Milled bread samples $(100 \mathrm{mg})$ were dispersing in distilled water $(5 \mathrm{ml})$ to ensure the full rehydration of samples. Before the in vitro digestion procedure, bread samples and simulated digestion fluids were inserted in a shaking water bath (B.BRAUN BIOTECH model CERTOMAT WR, Melsungen,Germany) with horizontal agitation of $120 \mathrm{rpm}$ at temperature of $37^{\circ} \mathrm{C}$.

Initially, samples were exposed to the simulation of the oral phase by adding SSF, $\mathrm{CaCl}_{2}\left(\mathrm{H}_{2} \mathrm{O}\right)$ (to achieve the concentration of $1.5 \mathrm{mmol} \mathrm{L}^{-1}$ ), $\alpha$-amylase (Sigma-Aldrich A1031, CAS 9000-90-2) (to obtain $75 \mathrm{U} \mathrm{mL}^{-1}$ activity), and milli-Q water (necessary volume to dilute the SSF stock solution). The samples were incubated at $37^{\circ} \mathrm{C}$ for 2 min. An aliquot of the samples were collected from the liquid medium in the end of oral phase ( $2 \mathrm{~min}$ ) and preserved under frozen conditions for later analysis. The passage through to stomach was mimicked by adding SGF, porcine pepsin solution (Sigma-Aldrich P7012; CAS 9001-75-6) (to achieve an activity of $2000 \mathrm{U} \mathrm{mL}^{-1}$ in the final mixture), $\mathrm{CaCl} 2\left(\mathrm{H}_{2} \mathrm{O}_{2}\right)$ (to obtain $0.15 \mathrm{mmol} \mathrm{L}^{-1}$ in the fluid). The $\mathrm{pH}$ value was adjusted to 3.0 with $1 \mathrm{mmol} \mathrm{L}^{-1} \mathrm{HCl}$, and the gastric phase volume was complete with milli-Q water. The sample was incubated at $37^{\circ} \mathrm{C}$ for $120 \mathrm{~min}$. During the gastric phase, An aliquot of the samples was collected every 30 min and preserved under frozen conditions for later analysis. The intestinal phase was simulated by adding of SIF, $\mathrm{CaCl}_{2}\left(\mathrm{H}_{2} \mathrm{O}_{2}\right)$ (to obtain $0.6 \mathrm{mmol} \mathrm{L}^{-1}$ in the fluid), pancreatin (Sigma-Aldrich P7545; CAS 8049-47-6) (to achieve the activity of $100 \mathrm{U} \mathrm{mL}^{-1}$ in the final mixture) and bile salts (Sigma-Aldrich B8631; CAS 8008-63-7) in a concentration of $80.0 \mathrm{mg}$ $\mathrm{mL}^{-1}$ (to obtain the concentration of $10 \mathrm{mmol} \mathrm{L}^{-1}$ in the final mixture). Pancreatin and bile solutions were both prepared in SIF. The $\mathrm{pH}$ value was adjusted to 7.0 using 1 $\mathrm{mmol} \mathrm{L}{ }^{-1} \mathrm{NaOH}$, when necessary. The final intestinal phase was adjusted with milli- 
$\mathrm{Q}$ water and incubated under the same conditions as before for $120 \mathrm{~min}$. An aliquot of the samples was collected every $30 \mathrm{~min}$ and preserved under frozen conditions for later analysis.

At the end of the intestinal phase, the enzymatic activity was stopped by adding 1 $\mathrm{mmol} / \mathrm{mL}$ of enzyme inhibitor pefabloc ${ }^{\circledR} \mathrm{SC}$. All samples were tested at least in triplicate.

\subsubsection{Measurements of starch fractions}

To determine the total hydrolyzed starch (HS) during the digestion the collected samples were firstly centrifuged at $5000 \times g$ for 10 min (MIKRO 120, Hettich, Germany). The supernatant was incubated with glucose GOPOD reagent from Megazyme (K-TSTA, Ireland) at $50{ }^{\circ} \mathrm{C}$ for 20 . The absorbance was measured at wavelength $510 \mathrm{~nm}$ (Synergy HT, Vermont, USA). The percentage of D-glucose was converted to percentage of starch with the factor of 0.9 (which represents the anhydrous D-glucose divided by free D-glucose molecular weight). Obtained values of starch available were normalized to percentage of hydrolyzed starch.

Using the data obtained in the in vitro digestion, starch fractions corresponding to rapidly digestible starch (RDS), slowly digestible starch (SDS), and resistant starch (RS) were determined by Eqs. [33]. Considering RDS as starch hydrolyzed during the oral phase (2 min), SDS as the maximum amount of starch hydrolyzed during gastric -intestinal phase and RS as starch that was not hydrolyzed. The following equations were applied:

$\% R D S=\% H S_{2}$

$\% S D S=\% H S_{150}-H S_{2}$ 
$\% R S=T S-\% H S$

where $\mathrm{HS}_{2}$ represents the percentage of total starch hydrolyzed in the oral phase after $2 \mathrm{~min}, H S_{150}$ is the percentage of total starch hydrolyzed after $150 \mathrm{~min}$ in intestinal phase, $H S$ is the percentage of total starch hydrolyzed until the end of the digestion.

\subsubsection{Determination of estimated glycemic index}

The glucose concentration determined during the in vitro digestion process was normalized to the percentage of total starch hydrolyzed. Then, the area under the curve $(A U C)$ of the total hydrolyzed starch during the in vitro digestion process (0240 min) was calculated using the GraphPad Prism 8 software. The AUC was used to provide the hydrolysis index $(H I)$ according to Equation 7 [34]:

$H I=\frac{A U C_{\text {sample }}}{A U C_{\text {ref }}} \times 100$

where $A U C_{\text {sample }}$ corresponds to the $A U C$ of the bread formulations and the $A U C_{\text {ref }}$ corresponds to the AUC of white bread.

The estimated glycemic index $(e G /)$ was determined as reported by Goñi et al., (1997), using the following Equation 8:

$e G I=39.71+(0.549 \times H I)$

(8)

\subsection{Statistical analysis}

This article is protected by copyright. All rights reserved. 
All experiments were carried out at least in triplicate and results were reported as the average \pm standard deviation $(S D)$. The statistical analysis was performed by oneway analysis of variance (ANOVA) followed by Tukey's test with a significance level of $5 \%$, using INFOSTAT software version 2018 for Windows (Córdoba, Argentina).

\section{Results and discussion}

\subsection{Nutritional Composition of POP}

Table 1 shows the results obtained from the evaluation of the chemical components and the energy value of the POP. The ash $(9.9 \pm 0.2 \mathrm{~g} / 100 \mathrm{~g})$ and crude fat $(1.9 \pm$ $0.1 \mathrm{~g} / 100 \mathrm{~g}$ ) content were similar as reported by other authors [35, 36]. P. ostreatus has also been described also as a source of minerals such as phosphorous, potassium and magnesium [37]. The crude protein content was $22.3 \pm 1.4 \mathrm{~g} / 100 \mathrm{~g}$, being the second greatest component found in the POP. The main component found in POP was carbohydrates $(60.3 \pm 0.7 \mathrm{~g} / 100 \mathrm{~g})$. Other authors have also reported that carbohydrates are the main macronutrient present in the $P$. ostreatus [38]. The result of the crude fiber content was $5.5 \pm 0.4 \mathrm{~g} / 100 \mathrm{~g}$. The nutritional content of the POP and other edible mushrooms is mainly affected by the substrates used for their cultivation. Edible mushrooms can be cultivated on various substrates, such as lignocellulosic residues, since they degrade this type of material and use them efficiently to grow [39]. In the present investigation the POP grew in wheat and sorghum straw. Wheat straw is the material commonly used for this purpose, and it can provide nutrients necessary for the fruiting of the mushrooms [40].

The energy value determined for the POP was $347.5 \pm 2.1 \mathrm{kcal} / 100 \mathrm{~g}$. Due to its low calorie content and nutritional contribution, mushrooms have be classified as healthy foods [41]. 


\subsection{Nutritional Composition of Pleurotus ostreatus wheat bread}

The nutritional composition of the breads formulated in the present work is shown in Table 2. The POP did not generate statistically significant changes in the moisture content of the breads (27.89 to $31.98 \%)(p \leq 0.05)$.

The $\mathrm{BPO}_{20}$ bread obtained a protein content of $1.55 \pm 0.12 \mathrm{~g} / 100 \mathrm{~g}$, with the highest concentration of POP (20\%), which represented that the POP increase a $40.9 \%$ the protein content compared to the CB with $1.10 \pm 0.15 \mathrm{~g} / 100 \mathrm{~g}$ of crude protein. There were no significant differences $(p \leq 0.05)$ between the formulations with POP. This registered behavior may be due to the fact that by reducing the amount of wheat flour in the formulation, its protein contribution is also reduced. Despite this, the POP managed to increase and maintain this increase registered in protein levels, despite the decrease in wheat flour. POP contains proteins of high biological value since it provides all the essential amino acids, while the wheat flour is lacking in lysine and threonine $[41,42]$. The POP on bread formulations promote an enhance of ash content $\mathrm{t}$ from $2.48 \pm 0.09 \mathrm{~g} / 100 \mathrm{~g}$ in $\mathrm{CB}$ to $3.77 \pm 0.21 \mathrm{~g} / 100 \mathrm{~g}$ in $\mathrm{BPO}_{20}$. The increase in the ash content in the bread can be attributed to the fact that the POP is a source of minerals as phosphorus, potassium, iron, copper and zinc [37]. There was no significant change $(p \leq 0.05)$ in the total carbohydrate content due to the addition of POP, although these were the majority component. It should be considered that unlike wheat flour that contains up to $75 \mathrm{~g} / 100 \mathrm{~g}$ starch [43] the polysaccharides of POP are fibers like $\beta$-glucans [44]. Regarding the crude fiber content, it increased as the concentration of POP in breads significantly increased ( $p$ $\leq 0.05$ ). POP could also increase the dietary fiber content in wheat bread, by containing in the cell walls $\beta$-glucans, which are soluble dietary fiber with benefits for 
human health [45]. This is important, because white wheat bread has a very low fiber content due to the nature of refined wheat flour, which has separated fractions rich in dietary fiber (the germ and the bran of the grain) [46].

Regarding the crude fat content of the breads, its content increased from $4.50 \pm 0.94$

$\mathrm{g} / 100 \mathrm{~g}$ in $\mathrm{CB}$ to $6.68 \pm 1.13 \mathrm{~g} / 100 \mathrm{~g}$ in $\mathrm{BPO}_{20}$. Mushroom includes monounsaturated and polyunsaturated fatty acids, which consume is related to a lowering risk of cardiovascular disease [47].

The energy value determined for the breads ranged from 289 to $319 \mathrm{kcal} / 100 \mathrm{~g}$, without statistically significant differences $(p \leq 0.05)$.

Fortifying wheat flour with POP can improve the nutritional quality of bakery products.

\subsection{Bread physical properties}

Table 3 shows the physical properties of the breads. The progressive addition of POP in the bread caused a significant increase $(p \leq 0.05)$ in the weight of the bread unit going from $38.78 \pm 0.34 \mathrm{~g}$ in $\mathrm{CB}$ to $41.74 \pm 0.06 \mathrm{~g}$ in $\mathrm{BPO}_{20}$ and an evident decrease in the volume of the bread (Fig 2.) The effect of the addition of POP on the physical properties of the bread has been significant, even at a lower concentration (4\%) than that used in the present investigation [48]. These physical changes may be due to the fact that the substitution of wheat flour with POP (gluten-free) affected the formation of a firm gluten network that would retain the $\mathrm{CO}_{2}$ produced during the fermentation of the dough with yeast, preventing an increase in volume [49]. In the present study, aguamiel was used as a source of sucrose, since it is known that sugar can activate yeast and increase the production of $\mathrm{CO}_{2}$ [50]. More studies are needed to know the effect of aguamiel in bakery products. 
There were also significant changes $(p \leq 0.05)$ in the color parameters of the crumb of breads enriched with POP (Fig 2). L * value corresponding to luminosity, decreased from $64.64 \pm 3.45$ in $\mathrm{CB}$ to $36.53 \pm 1.90$ in $\mathrm{BPO}_{20}$. Mushrooms powder are slightly darkener than refined wheat flour, which may explain the browning effect [51].

There was also a significant increase $(p \leq 0.05)$ in the parameters $a *$ and $b$ *, which represent the red and yellow pigments, respectively. The appearance of red and yellow pigments is also associated with the Mailard reaction and caramelization of sugars during the baking of bread dough [52]. These changes may be due to chemical reactions that occur during baking, between the phenolic compounds, in the sugars and proteins contained in the mushrooms, thus altering the final color of the product [53].

\subsection{In vitro digestion of starch and determination of nutritionally important starch fractions}

The standardized INFOGEST protocol was used to study the in vitro digestibility of wheat bread starch with different amounts of POP. The starch digestion curves for bread enriched with POP are shown in Figure 3. In general, all bread samples showed a similar digestion curve in which the total starch hydrolysis rate increased markedly at $150 \mathrm{~min}$, during intestinal digestion, achieving equilibrium in this phase. The starch digestion has been described to begin in the oral phase, during chewing, due to the action of the salivary a-amylase enzyme [54]. After the bread samples passed from the oral to the gastric phase, the hydrolyzed starch remained similar, with no statistically significant differences between both phases $(p>0.05)$. Conditions during the gastric phase were simulated to human physiological conditions, gastric conditions were similar to those described by Simões et al (2020), they were 
characterized by high ionic strength (values around $100 \mathrm{mmol} \mathrm{L}-1$ ) and acidity (a $\mathrm{pH}$ value of 3 ) and these conditions inhibit the action of $\alpha$-amylase and the hydrolysis of the starch was interrupted. In human digestion, the change in $\mathrm{pH}$ is gradual and enzymatic work continues, so that starch digestion continues even during the gastric phase [54], in the protocol carried out for the simulation of digestion, the change in $\mathrm{pH}$ was immediate, so the digestion of the starch was interrupted during this phase [56]. Results from the intestinal phase (Figure 3), demonstrated that the maximum starch hydrolyze was obtained at $150 \mathrm{~min}$. These behavior can be attributed to starch availability to be hydrolyzed by $\alpha$-amylase pancreatic enzymes when its function is favored by raising the $\mathrm{pH}$ to 7.0 [57-58]. Nevertheless, a significant decrease in total starch hydrolysis rate was observed with increased amount of POP, indicating that the addition of POP could reduce starch digestibility of bread.

In order to predict the nutritionally important fractions of starch of bread, the total starch content (TS) and the results obtained during in vitro digestion process were used to determine the total starch hydrolyzed (HS), rapidly digested starch (RDS), slowly digested starch (SDS) and resistant starch (RS) and estimated glycemic index (eGI).

The addition of POP in the wheat bread formulation decreased the TS from $99.33 \%$ in $\mathrm{CB}$ to $66.53 \%$ in $\mathrm{BPO}_{20}$. Wheat flour is rich in starch [43], while POP has other types of carbohydrates. By reducing the wheat flour in the formulation and adding POP, the amount of starch present in the bread is decreased. A lower starchy bread can be included in a diet where carbohydrates are controlled. The consumption of low carbohydrate products is an appropriate approach to lose weight, with an impact on health, since obesity is associated with various chronic diseases such as cardiovascular disease, cancer, diabetes [59]. HS decreased significantly during in 
vitro digestion ( $p \leq 0.05$ ), presenting the lowest $\mathrm{HS}$ value of $35.24 \%$ in bread $\mathrm{BPO}_{20}$, compared to the CB which was $41.73 \%$.

The results on bread starch content (Table 5) revealed that the addition of POP in bread promoted a decrease in the content of RDS ( $p \leq 0.05)$. In this study, the bread formulations presented less than 3\% RDS, this can be explained by the inhibition of the action of $\alpha$-amylase by the acidic $\mathrm{pH}$ when passing from the oral to the gastric phase in the in vitro digestion protocol INFOGEST. These facts were accompanied by an increase in SDS values ( $p \leq 0.05)$.

These changes have been reported when low-starch and high-dietary fiber ingredients, as POP, are added to wheat bread [60]. The digestion of carbohydrates is compromised by different factors. As mentioned above, fortifying bread with POP increased the content of crude fiber, protein and fat (Table 2) and these components could interfere with the digestion of starch. A decrease in HS has been recorded during in vitro digestion of pasta enriched with $15 \%$ mushroom powder (porcini and shitake mushroom powder) [43]. Also, another reason why POP could decrease starch digestion, as observed in the RSD and SDS behavior of bread, could be due to the fact tha POP contains a large amount of dietary fibeR that could change the properties of the starch system, such as viscosity and degree of swelling. The dietary fiber in POP was also able to surround the starch granules, causing their swelling and gelatinization to be suppressed, and reducing the starch's susceptibility to digestive enzymes $[4,44]$.

The RS is a fraction of starch that can resist digestion and remains intact throughout the gastrointestinal tract, it can be fermented by bacteria in the colon and is associated with lower levels of blood glucose and plasma cholesterol [61]. In this study, the RS progressively decrease from 57.60 in $C B$ to $31.29 \%$ as the 
concentration of POP increase in the bread formulations. The highest percentage of RS is desired, due to its physiological effects in the gut (similar to fibers), which is also described as beneficial to health in diet-related non-communicable diseases. In this study, when replacing wheat flour rich in starch with another ingredient that was not a source of starch, such as POP, the amount of RS starch was also decreased. The lower the total starch concentration and lower amylose content, the lower the RS percentage. Studies have related, the amount of amylose present in starch is related to lower percentages of RS [62].

Bread formulated with wheat flour, used as a control (CB), obtained the eGI of 100 . The addition of POP in the bread formulations promoted the reduction of eGI ( $p \leq$ 0.05), wherethe addition of $20 \%$ of $\mathrm{POP}$ in the bread $\mathrm{BPO}_{20}$ obtained a decrease of more than $25 \%$ in the $\mathrm{eGI}$ of 72.21 in comparison with the CB. The reduction of eGI in bread formulations can be attributed to the fact that POP was a source of components, such soluble dietary fiber, as $\beta$-glucans. Dietary fibers have been shown to reduce $\mathrm{GI}$ when added to food products. Soluble fibers absorb water in low water conditions, limiting gelatinization of starch. Therefore, the accessibility of pancreatic amylase enzymes to act on partially gelatinized starch is reduced $[19,63]$. A diet rich in low-glycemic foods has been associated with several health benefits, for instance, lower insulin demand, blood glucose control, and lower blood lipid levels, which could prevent or treat of chronic diseases (e.g., diabetes, heart disease and some types of cancer) [64]. In vivo studies are required to determine the hypoglycemic effect of the addition of POP in food formulations. There were no significant differences between the $\mathrm{BPO}_{15}$ and $\mathrm{BPO}_{20}$ formulation, so it can be used from $15 \%$ POP to achieve a significant decrease in eGI. 
The results of in vitro simulated gastrointestinal digestion demonstrated that bread supplemented with POP showed more optimal starch digestibility with slower digestion rate, lower eGI and RDS contents, which could bring health benefits to humans. Sensory studies are needed to determine that formulations with high concentrations of POP do not affect the acceptability of the product.

\section{Concluding remarks}

The incorporation of POP improved the nutritional composition of bread formulations. The chemical characterization demonstrated that the addition from $5 \%$ of POP in the bread caused an increase in the content of protein, fiber, and minerals (ash). Replacing high-starch wheat flour with edible mushrooms reduced the amount of TS in the formulations. The in vitro digestion results indicated an improvement SDS starch fraction in the POP formulated bread. From the addition of $15 \%$ of POP, the greatest nutritional increases and reduction of eGI were presented. Therefore, the POP could be used as an alternative food ingredient to improve nutritional quality and reduce the glycemic index of bread. However, it is important that the incorporation of mushrooms does not negatively affect the physical and sensory quality of the bread, which is why additional studies on these parameters are needed. Is a trend to found sources of sugars with health benefits, such as aguamiel which was used in this work as an alternative to sucrose in bread formulations. However, in this study, the effects of aguamiel in bakery products was not the objective, which is why more research is needed on its properties and effects in these products.

\section{Author contributions}


Study concept and design: R.B., M.C. and C.L. Method development, sample preparation, sample analysis and interpretation of data: C.L., C.N., L.S.S and A.L Preparation of the manuscript: C.L., R.B., M.C. and C.N. Study supervision and resources: R.B., M.C., R.M.R and J.T.

\section{Conflict of interest statement}

The authors declare "no conflict of interest" exists in this reported work.

\section{Acknowledgments}

This work was financed by the National Council of Science and Technology (CONACYT) Mexico through the institutional program CONACYT-S923148.

This study was also supported by the Foundation for Science and Technology (FCT) under the scope of the strategic funding of UID/BIO/04469/2019 unit and BioTecNorte operation(NORTE-01-0145-FEDER-000004) funded by the European Regional Development Fund under the scope of Norte2020 Programa Operacional Regional do Norte and the Project ColOsH PTDC/BTMSAL/30071/2017 (POCI-01-0145-FEDER-030071).

\section{References}

[1] U. K. Ibrahim, R. M. Salleh, and S. N. S. Maqsood-ul-Haque, Bread towards Functional Food: An Overview, ETP Int. J. Food Eng 2015, 1, 39-43. https://doi.org/10.18178/ijfe.1.1.39-43

[2] K. Dewettinck, F. Van Bockstaele, B. Kühne, D. Van de Walle, T. M. Courtens, and X. Gellynck, Nutritional value of bread: Influence of processing, food interaction and consumer perception, J. Cereal Sci 2008, 48, 243-257. 
https://doi.org/ 10.1016/j.jcs.2008.01.003

[3] A. SRV A., Mishra, S., Hardacre, A., Matia-Merino, L., Goh, K., Warren, F., \& Monro, J. Kernel structure in breads reduces in vitro starch digestion rate and estimated glycaemic potency only at high grain inclusion rates, Food Struct 2019, 21, https://doi.org/ 10.1016/j.foostr.2019.100109

[4] Y. Chen, L. Zhao, T. He, Z. Ou, Z. Hu, and K. Wang, Effects of mango peel powder on starch digestion and quality characteristics of bread, Int. J. Biol. Macromol 2019,140, 647. https://doi.org/ 10.1016/j.ijbiomac.2019.08.188

[5] G. Ma, W. Yang, L. Zhao, F. Pei, D. Fang, and Q. Hu, A critical review on the health promoting effects of mushrooms nutraceuticals, Food Sci. Hum. Wellness, 2018, 7, 125-133. https://doi.org/10.1016/j.fshw.2018.05.002

[6] A. Krakowska et al., Selected edible medicinal mushrooms from Pleurotus genus as an answer for human civilization diseases, Food Chem 2020, 327. https://doi.org/10.1016/j.foodchem.2020.127084

[7] F. S. Reis, A. Martins, M. H. Vasconcelos, P. Morales, and I. C. F. R. Ferreira, Functional foods based on extracts or compounds derived from mushrooms, Trends Food Sci. Technol 2017, 66,48-62 https://doi.org/ 10.1016/j.tifs.2017.05.010

[8] P. Kalač, Edible Mushrooms. Elsevier, 2016.

[9] M. Nadhim, Green synthesis of silver nanoparticles by Pleurotus (oyster mushroom ) and their bioactivity: Review, Environ. Nanotechnology, Monit. Manag., 2019, 12. https://doi.org/ 10.1016/j.enmm.2019.100256

[10] M. B. Bellettini, F.A. Fiorda, H.A. Maieves, G. Lopes, S. Ávila, P. Silveira, A. Maccari, R. Hoffmann, Factors affecting mushroom Pleurotus spp, Saudi J. Biol. Sci, 2019, 26, 633-646. https://doi.org/10.1016/j.sjbs.2016.12.005

[11] V. Vetvicka, O. Gover, M. Karpovsky, H. Hayby, O. Danay, N. Ezov, Y. Hadar, 
B. Schwartz, Immune-modulating activities of glucans extracted from Pleurotus ostreatus and Pleurotus eryngii, J. Funct. Foods 2019, 54, 81-91. https://doi.org/10.1016/j.jff.2018.12.034

[12] A. Synytsya, A., Míčková, K., Synytsya, A., Jablonský, I., Spěváček, J., Erban, V.,Čopíková, J. Glucans from fruit bodies of cultivated mushrooms Pleurotus ostreatus and Pleurotus eryngii: Structure and potential prebiotic activity, Carbohydr. Polym 2009, 76, 548-556. https://doi.org/10.1016/j.carbpol.2008.11.021

[13] Y. Zhang, T. Hu, H. Zhou, Y. Zhang, G. Jin, and Y. Yang, Antidiabetic effect of polysaccharides from Pleurotus ostreatus in streptozotocin-induced diabetic rats, Int. J. Biol. Macromol 2016, 83,126-132. http://dx.doi.org/10.1016/j.ijbiomac.2015.11.

[14] C. C. Nweze, N. O. Rasaq, and B. I. Istifanus, Effect of Agaricus bisponus and Pleurotus ostreatus mixed diet on Alloxan-induced hyperglycemic rats, Sci. African 2020,7. https://doi.org/10.1016/j.sciaf.2019.e00209

[15] M. Bhattacharya, P. P. Srivastav, and H. N. Mishra, Optimization of process variables for supercritical fluid extraction of ergothioneine and polyphenols from Pleurotus ostreatus and correlation to free-radical scavenging activity,J. Supercrit. Fluids 2014, 95,51-59. http://dx.doi.org/10.1016/j.supflu.2014.07.031

[16] Z. Qing, J. Cheng, X. Wang, D. Tang, X. Liu, and M. Zhu, The effects of four edible mushrooms (Volvariella volvacea, Hypsizygus marmoreus, Pleurotus ostreatus and Agaricus bisporus) on physicochemical properties of beef paste, LWT, 2020, 135. https://doi.org/10.1016/j.colsurfa.2020.124658

[17] M. Khider, O. Seoudi, and Y. F. Abdelaliem, Functional Processed Cheese Spreads with High Nutritional Value as Supplemented with Fresh and Dried $\begin{array}{lllllll}\text { Mushrooms, Int. J. Nutr. Food } & \text { J. }\end{array}$ https://doi.org/10.11648/j.jijnfs.20170601.18 
[18] A. C. Pelaes, P. Akie, L. N. Hanai,S. M Gomes-da-costa, B. Alves, C. Vatura, and P. Toshimi. Microbiological, functional and rheological properties of low fat yogurt supplemented with Pleurotus ostreatus aqueous extract, LWT - Food Sci. Technol 2015, 64, 1028-1035 http://dx.doi.org/10.1016/j.Iwt.2015.07.003

[19] S. H. Ng, S. D. Robert, W. A. N. Wan Ahmad, and W. R. Wan Ishak, Incorporation of dietary fibre-rich oyster mushroom (Pleurotus sajor-caju) powder improves postprandial glycaemic response by interfering with starch granule structure and starch digestibility of biscuit, Food Chem 2017, 227, 358-368. http://dx.doi.org/10.1016/j.foodchem.2017.01.108

[20] S. Kim, J. W. Lee, Y. Heo, and B. Moon, Effect of Pleurotus eryngii Mushroom $\beta$-Glucan on Quality Characteristics of Common Wheat Pasta, J. Food Sci, 2016, 81, C835-C840. http://dx.doi.org/10.1111/1750-3841.13249

[21] F. J. Vicente-Magueyal, A. Bautista-Méndez, H. D. Villanueva-Tierrablanca, J. L. García-Ruíz, H. Jiménez-Islas, and J. L. Navarrete-Bolaños, Novel process to obtain agave sap (aguamiel) by directed enzymatic hydrolysis of agave juice $\begin{array}{llllll}\text { fructans, } & L W T & - & \text { Food } & \text { Sci. } & \text { Technol 2020, }\end{array}$ http://dx.doi.org/10.1016/j.Iwt.2020.109387

[22] A. Escalante, D. R. López Soto, J. E. Velázquez Gutiérrez, M. Giles-Gómez, F. Bolívar, and A. López-Munguía, Pulque, a traditional Mexican alcoholic fermented beverage: Historical, microbiological, and technical aspects, Front. Microbiol 2016, 7, 1-18 http://dx.doi.org/10.3389/fmicb.2016.01026

[23] D. B. Muñiz-Márquez, J. C.Contreras, R. Rodriguez, S.Mussatto, J. WongPaz, J. A. Teixeira, C. N. Aguilar. Influence of thermal effect on sugars composition of Mexican Agave syrup, CYTA - J. Food 2015, 13, 607-612. http://dx.doi.org/10.1080/19476337.2015.1028452 
[24] R. I. Ortiz-Basurto, G. Pourcelly, T. Doco, P. Williams, M. Dormer, and M. P. Belleville, Analysis of the main components of the aguamiel produced by the maguey-pulquero (Agave mapisaga) throughout the harvest period, J. Agric. Food Chem 2008, 56, 3682-3687. http://dx.doi.org/10.1021/jf072767h

[25] O. de la Rosa, A. C. Flores-Gallegos, D. Muñíz-Marquez, C. Nobre, J. C. Contreras-Esquivel, and C. N. Aguilar, Fructooligosaccharides production from agrowastes as alternative low-cost source, Trends Food Sci. Technol 2019, 91, 139-146. https://doi.org/10.1016/j.tifs.2019.06.013

[26] Y. Shen, G. Chen, and Y. Li, Bread characteristics and antioxidant activities of Maillard reaction products of white pan bread containing various sugars, Lwt 2018, 95, 308-315. https://doi.org/10.1016/j.Iwt.2018.05.008

[27] A.O.A.C., Official Methods of Analysis. Association of Official Analytica Chemist. EUA, 2000.

[28] M. Rasalanavho, R. Moodley, and S. B. Jonnalagadda, Elemental bioaccumulation and nutritional value of five species of wild growing mushrooms $\begin{array}{llll}\text { from South } \quad \text { Africa, } & \text { Food }\end{array}$ https://doi.org/10.1016/j.foodchem.2020.126596

[29] A. Hoehnel, C. Axel, J. Bez, E. K. Arendt, and E. Zannini, Comparative analysis of plant-based high-protein ingredients and their impact on quality of highprotein bread, J. Cereal Sci 2019, 89. https://doi.org/10.1016/j.jcs.2019.102816 [30] FAO, "FAO Food and Nutrition paper 77. Food energy - methods of anlysis and conversion factors," 2003.

[31] 11th Edition - AACC Approved Methods of Analysis, AACC Method 10-05.01. Guidelines for Measurement of Volume by Rapeseed Displacement." [Online]. Available: http://methods.aaccnet.org/summaries/10-05-01.aspx. 
[32] M. Minekus Alminger, M., Alvito, P., Ballance, S., Bohn, T., Bourlieu, C., ... Brodkorb, A. , Function suitable for food - an international consensus †," Food Funct 2014, 5,1113-1124. https://doi.org/10.1039/c3fo60702j

[33] H. N. Englyst, S. M. Kingman, and J. H. Cummings, Classification and measurement of nutritionally important starch fractions, Eur. J. Clin. Nutr 1992, 46.

[34] F. Goñi, Isabel. García-Alonso, Alejandra. Saura-Calixto, A starch hydrolysis procedure to estimate glycemic index., Nutr. Reasearch, 1997, 17.

[35] N. Alam. R. Amin, A. Khan, I. Ara, M. Ja, M. Woong, T. Soo. Nutritional Analysis of Cultivated Mushrooms in Bangladesh - Pleurotus ostreatus , Pleurotus sajor-caju , Pleurotus florida and Calocybe indica , Mycobiology 2008,36, https://doi.org/10.4489/MYCO.2008.36.4.228

[36] Wang, S., Xu, F., Li, Z., Zhao, S., Song, S., Rong, Geng, X and Liu, Y. The spent mushroom substrates of Hypsizigus marmoreus can be an effective component for growing the oyster mushroom Pleurotus ostreatus," Sci. Hortic. (Amsterdam) 2015,186, 217-222, https://doi.org/10.1016/j.scienta.2015.02.028

[37] F. Bach, C. V. Helm, M. B. Bellettini, G. M. Maciel, and C. W. I. Haminiuk, Edible mushrooms: a potential source of essential amino acids, glucans and minerals, Int. J. Food Sci. Technol 2017, 52, 2382-2392, https://doi.org/10.1111/ijfs.13522

[38] Â. Fernandes, L. Barros, A. Martins, P. Herbert, and I. C. F. R. Ferreira, Nutritional characterisation of Pleurotus ostreatus (Jacq. ex Fr.) P. Kumm. produced using paper scraps as substrate, Food Chem 2015, 169, 396-400. https://doi.org/10.1016/j.foodchem.2014.08.027

[39] G. Koutrotsios, K. C. Mountzouris, I. Chatzipavlidis, and G. I. Zervakis, Bioconversion of lignocellulosic residues by Agrocybe cylindracea and Pleurotus 
ostreatus mushroom fungi-Assessment of their effect on the final product and spent substrate properties, Food Chem 2014, 161, 127-135, http://dx.doi.org/10.1016/j.foodchem.2014.03.121

[40] W. A. Wan Mahari. P. Wanxi, N. Wai, H. Yang, X. Lee, Y Lee, R. Liew , N. Ma, A. Mohammad, C Sonne, Q.V.V Le, P.L. Show, W-H, Chen and S. Shiung. A review on valorization of oyster mushroom and waste generated in the mushroom $\begin{array}{lllll}\text { cultivation industry, } & \text { J. Hazard. } & \text { Mater }\end{array}$ https://doi.org/10.1016/j.jhazmat.2020.123156

[41] P. Manzi, L. Gambelli, S. Marconi, V. Vivanti, and L. Pizzoferrato, Nutrients in edible mushrooms: An inter-species comparative study, Food Chem 1999, 65, 477482. https://doi.org/10.1016/S0308-8146(98)00212-X

[42] D. Guardado-félix, M. A. Lazo-vélez, E. Pérez-carrillo, D. Esteban, and S. O. Serna-saldivar, Effect of partial replacement of wheat flour with sprouted chickpea flours with or without selenium on physicochemical, sensory, antioxidant and protein quality of yeast-leavened breads, LWT - Food Sci. Technol 2020, 129. https://doi.org/10.1016/j.Iwt.2020.109517

[43] X. Lu, M. A. Brennan, L. Serventi, J. Liu, W. Guan, and C. S. Brennan, Addition of mushroom powder to pasta enhances the antioxidant content and modulates the predictive glycaemic response of pasta, Food Chem 2018, 264, 199 209. https://doi.org/10.1016/j.foodchem.2018.04.130

[44] S. Zhou, F. Ma, X. Zhang, and J. Zhang, Carbohydrate changes during growth and fruiting in Pleurotus ostreatus, Fungal Biol 2016, 120, 852-861. http://dx.doi.org/10.1016/j.funbio.2016.03.007

[45] J. Rodrigues Barbosa, M. M. dos Santos Freitas, L. H. da Silva Martins, and R. N. de Carvalho, Polysaccharides of mushroom Pleurotus spp.: New extraction 
techniques, biological activities and development of new technologies, Carbohydr. Polym 2020, 229. https://doi.org/10.1016/j.carbpol.2019.115550

[46] P. Geng, J. M. Harnly, and P. Chen, Differentiation of bread made with whole grain and refined wheat ( $T$. aestivum) flour using LC/MS-based chromatographic fingerprinting and chemometric approaches, J. Food Compos. Anal 2016,47, 92100. http://dx.doi.org/10.1016/j.jfca.2015.12.010

[47] R. M. O. Kayode, T. F. Olakulehin, B. S. Adedeji, O. Ahmed, T. H. Aliyu, and A. H. A. Badmos, Evaluation of amino acid and fatty acid profiles of commercially cultivated oyster mushroom (Pleurotus sajor-caju) grown on gmelina wood waste, Niger. Food J 2015, 33, 18-21. http://dx.doi.org/10.1016/j.nifoj.2015.04.001 [48] G.-H. Hong, Y.-S. Kim, and G.-S. Song, Effect of Oyster Mushroom (Pleurotus ostreatus) Powder on Bread Quality, Preventive Nutrition and Food Science 2005,10, 214-218. http://dx.doi.org/10.3746/jfn.2005.10.3.214

[49] K. A. Millar, C. Barry-Ryan, R. Burke, S. McCarthy, and E. Gallagher, Dough properties and baking characteristics of white bread, as affected by addition of raw, germinated and toasted pea flour, Innov. Food Sci. Emerg. Technol 2019, 56, https://doi.org/10.1016/j.ifset.2019.102189

[50] O. Parenti, L. Guerrini, B. Cavallini, F. Baldi, and B. Zanoni, Breadmaking with an old wholewheat flour: Optimization of ingredients to improve bread quality, $L w t$ 2020, 121, https://doi.org/10.1016/j.Iwt.2019.108980

[51] Y. Zhang, C. Ruan, Z. Cheng, Y. Zhou, and J. Liang, Mixolab behavior, quality attributes and antioxidant capacity of breads incorporated with Agaricus bisporus, J. Food Sci. Technol 2019, 56, 3921-3929. https://doi.org/10.1007/s13197-019-038597

[52] Y. M. Mohd Jusoh, N. L. Chin, Y. A. Yusof, and R. Abdul Rahman, Bread 
crust thickness measurement using digital imaging and $\mathrm{L}$ a $\mathrm{b}$ colour system, J. Food Eng 2009, 94, 366-371. http://dx.doi.org/10.1016/j.jfoodeng.2009.04.002

[53] Yuan, B., Zhao, L., Yang, W., McClements, D. J., \& Hu, Q. (2017). Enrichment of Bread with Nutraceutical-Rich Mushrooms: Impact of Auricularia auricula (Mushroom) Flour Upon Quality Attributes of Wheat Dough and Bread. Journal of Food Science, 82(9), 2041-2050. https://doi.org/10.1111/1750-3841.13812

54] D. Freitas, S. Le Feunteun, M. Panouillé, and I. Souchon, The important role of salivary a-amylase in the gastric digestion of wheat bread starch, Food Funct 2018, 9, 200-208. http://dx.doi.org/10.1039/C7FO01484H

[55] L. S. Simões, J. T. Martins, A. C. Pinheiro, A. A. Vicente, and O. L. Ramos, $\beta-$ lactoglobulin micro- and nanostructures as bioactive compounds vehicle: In vitro studies, Food Res. Int 2020,131. https://doi.org/10.1016/j.foodres.2020.108979

[56] K. Wojtunik-Kulesza, A. Oniszczuk, T. Oniszczuk, M. Combrzyński, D. Nowakowska, and A. Matwijczuk, Influence of in vitro digestion on composition, bioaccessibility and antioxidant activity of food polyphenols-a non-systematic review, Nutrients 2020, 12. https://doi.org/10.3390/nu12051401

[57] Gropper, S. S., Smith, J. L., \& Groff, J. L. (2009). Advanced Nutrition and Human Metabolism.

[58] Scazzina, F., Siebenhandl-Ehn, S., \& Pellegrini, N. (2013). The effect of dietary fibre on reducing the glycaemic index of bread. British Journal of Nutrition, 109(7), 1163-1174. https://doi.org/10.1017/S0007114513000032

[59] B. C. Johnston, S. Kanters, K. Bandayrel, P. Wu, F. Naji, R. A. Siemieniuk, G. D.C Ball, J. W. Busse, K. Thorlund, G. Guyatt, J. P. Jansen, E.J. Mills. Comparison of weight loss among named diet programs in overweight and obese adults: A metaanalysis, JAMA - J. Am. Med. Assoc 2014, 312, 923-933. https://doi.org 
/10.1001/jama.2014.10397

[60] N. Wang, Y. Xu, H. Chao, M. Zhang, Y. Zhou, and M. Wang, Effects of celery powder on wheat dough properties and textural, antioxidant and starch digestibility properties of bread, J. Food Sci. Technol 2020, 57, 1710-1718. https://doi.org/10.1007/s13197-019-04204-8

[61] C. M. Brites, M. J. Trigo, B. Carrapiço, M. Alviña, and R. J. Bessa, Maize and resistant starch enriched breads reduce postprandial glycemic responses in rats, Nutr. Res 2011, 31, 302-308. http://dx.doi.org/10.1016/j.nutres.2011.02.001

[62] F. Jean M, M. Daniel A, P. Ana C, V. António A. Rice in vitro digestion: application of INFOGEST harmonizedprotocol for glycemic index determination and starchmorphological study, J Food Sci Technol 2019. https://doi.org/10.1007/s13197-019-04174-x

[63] Y. M. Cassidy, E. M. McSorley, and P. J. Allsopp, Effect of soluble dietary fibre on postprandial blood glucose response and ts potential as a functional food ingredient, J. Funct. Foods, 2018, 46, 423-439 https://doi.org/10.1016/j.jff.2018.05.019

[64] D. W. K. Toh, E. S. Koh, and J. E. Kim, Lowering breakfast glycemic index and glycemic load attenuates postprandial glycemic response: A systematically searched meta-analysis of randomized controlled trials, Nutrition 2020, 71. https://doi.org/10.1016/j.nut.2019.110634 
Table 1. Chemical composition and the energetic value of Pleurotus ostreatus powder (POP).

\begin{tabular}{cc}
\hline $\begin{array}{c}\text { Chemical composition } \\
\text { Moisture (\%) }\end{array}$ & $\mathbf{g} / \mathbf{1 0 0} \mathbf{g}$ \\
\hline Ash & $9.9 \pm 0.2$ \\
Crude fat & $1.9 \pm 0.1$ \\
Crude protein & $22.3 \pm 1.4$ \\
Carbohydrates & $60.3 \pm 0.7$ \\
Crude fiber & $5.5 \pm 0.4$ \\
& $347.5 \pm 2.1$ \\
\hline Energetic value (kcal/100 g) &
\end{tabular}

Values presented correspond to mean and standard deviations on a dry basis. 
Table 2. Moisture, ash, crude fat, crude protein, total carbohydrates (TC), crude fiber (CF) and energetic value (EV) of bread formulations.

\begin{tabular}{|c|c|c|c|c|c|c|c|}
\hline Sample & $\begin{array}{c}\text { Moisture } \\
(\%)\end{array}$ & $\begin{array}{l}\text { Ash } \\
(g / 100 \\
g)\end{array}$ & $\begin{array}{c}\text { Fat } \\
(g / 100 \\
\text { g) }\end{array}$ & $\begin{array}{l}\text { Protein } \\
\text { (g/100 } \\
\text { g) }\end{array}$ & $\begin{array}{c}\text { CF } \\
(g / 100 \\
g)\end{array}$ & $\begin{array}{c}\text { TC } \\
(g / 100 \\
g)\end{array}$ & $\begin{array}{c}\text { EV } \\
\text { (kcal/100 } \\
\text { g) }\end{array}$ \\
\hline \multirow[t]{2}{*}{ CB } & $27.89 \pm$ & $2.48 \pm$ & $4.50 \pm$ & $1.10 \pm$ & $0.06 \pm$ & $64.00 \pm$ & $289.18 \pm$ \\
\hline & $1.37^{a}$ & $0.09^{a}$ & $0.94^{a}$ & $0.15^{\mathrm{a}}$ & $0.02^{a}$ & $2.31^{a}$ & $1.18^{a}$ \\
\hline \multirow[t]{2}{*}{$\mathrm{BPO}_{5}$} & $24.52 \pm$ & $2.89 \pm$ & $6.11 \pm$ & $1.46 \pm$ & $0.21 \pm$ & $64.74 \pm$ & $290.17 \pm$ \\
\hline & $2.14^{a}$ & $0.12^{\mathrm{ab}}$ & $1.27^{\mathrm{ab}}$ & $0.06^{b}$ & $0.01^{b}$ & $2.90^{a}$ & $2.40^{a}$ \\
\hline
\end{tabular}

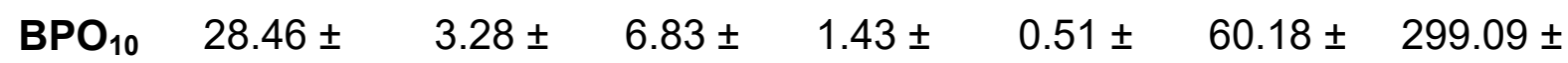
$3.28^{\mathrm{a}}$
$0.09^{\mathrm{bc}}$
$0.55^{\mathrm{ab}}$
$0.03^{b}$
$0.07^{\mathrm{bc}}$
$5.24^{\mathrm{a}} \quad 3.56^{\mathrm{a}}$

BPO $_{15} \quad 31.98 \pm$

$3.79 \pm$

$7.14 \pm \quad 1.48 \pm$

$0.73 \pm$

$54.99 \pm \quad 300.84 \pm$

$4.95^{a}$

$0.34^{d}$

$0.12^{b}$

$0.16^{b}$

$0.02^{\mathrm{c}}$

$4.90^{\mathrm{a}}$

$2.89^{a}$

$\mathrm{BPO}_{20} \quad 29.07$

$3.77 \pm \quad 6.68 \pm \quad 1.55 \pm$

$0.76 \pm$

$58.19 \pm \quad 319.77 \pm$

$\pm 1.45^{\mathrm{a}}$

$0.21^{\mathrm{cd}}$

$1.13^{\mathrm{ab}}$

$0.12^{b}$

$0.04^{\mathrm{c}} \quad 1.90^{\mathrm{a}}$

$5.72^{\mathrm{a}}$

Values presented correspond to mean and standard deviations on a dry basis. a,b,c,d Different superscript letters indicate a statistical difference in mean values of the same column ( $p \leq 0.05)$. CB: control bread, 0\% POP; $\mathrm{BPO}_{5}$ : bread with $5 \%$ of POP; $\mathrm{BPO}_{10}$ : bread with $10 \%$ of POP; $\mathrm{BPO}_{15}$ : bread with $15 \%$ of POP; $\mathrm{BPO}_{20}$ : bread with $20 \%$ of POP. 
Table 3. Specific volume and value of $L^{*}, a^{*}$ and $b^{*}$ of bread formulated with different proportion ranging from 0 to $20 \%$ of Pleurotus ostreatus powder (POP).

\section{Color}

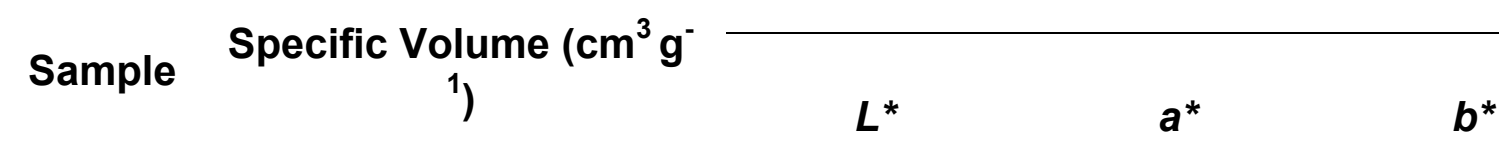

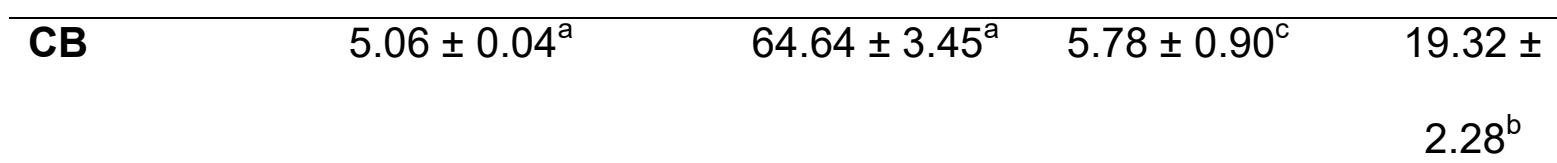

\begin{tabular}{|c|c|c|c|}
\hline $\mathrm{BPO}_{5}$ & $4.14 \pm 0.14^{b}$ & $53.89 \pm 4.80^{b}$ & $11.13 \pm$ \\
\hline & & & $11.53^{b}$ \\
\hline
\end{tabular}

$\mathrm{BPO}_{10}$

$3.48 \pm 0.15^{\mathrm{c}}$

$47.29 \pm \quad 12.92 \pm 1.11^{\text {ab }} \quad 26.20 \pm$

$1.23^{\mathrm{bc}}$

$1.13^{\mathrm{a}}$

$\mathrm{BPO}_{15}$

$3.33 \pm 0.15^{\mathrm{c}}$

$41.90 \pm \quad 13.31 \pm 0.70^{\mathrm{ab}}$

$24.77 \pm$

13

$1.76^{\mathrm{cd}}$

$1.10^{\mathrm{a}}$

$\mathrm{BPO}_{20}$

$2.64 \pm 0.29^{d}$

$36.53 \pm 1.90^{\mathrm{d}}$

$14.36 \pm 0.09^{\mathrm{a}}$

$24.47 \pm$

$0.26^{\mathrm{a}}$

a,b,c,d Different superscript letters indicate a statistical difference in mean values of the same column $(p \leq 0.05)$.

CB: control bread, $0 \% \mathrm{POP}$; $\mathrm{BPO}_{5}$ : bread with $5 \%$ of $\mathrm{POP}$; $\mathrm{BPO}_{10}$ : bread with $10 \%$ of POP; $\mathrm{BPO}_{15}$ : bread with $15 \%$ of POP; $\mathrm{BPO}_{20}$ : bread with $20 \%$ of POP. 
Table 4. Total starch (TS), total starch hydrolyzed (HS), rapidly digested starch (RDS), slowly digested starch (SDS), resistant starch (RS) and estimated glycemic index (eGI) of breads.

\begin{tabular}{|c|c|c|c|c|c|c|}
\hline \multirow[t]{2}{*}{ Sample } & TS & $R D S$ & SDS & $R S$ & $H S$ & \multirow[t]{2}{*}{ eGI } \\
\hline & $(\%)$ & $(\%)$ & $(\%)$ & $(\%)$ & $(\%)$ & \\
\hline \multirow[t]{2}{*}{ CB } & $99.33 \pm$ & $1.92 \pm$ & $39.36 \pm$ & $57.60 \pm$ & $41.73 \pm$ & $100.00 \pm$ \\
\hline & $9.06^{b}$ & $0.32^{b}$ & $1.21^{\mathrm{c}}$ & $0.23^{d}$ & $0.85^{c}$ & $1.30^{c}$ \\
\hline \multirow[t]{2}{*}{$\mathrm{BPO}_{5}$} & $97.65 \pm$ & $2.66 \pm$ & $37.29 \pm$ & $57.24 \pm$ & $40.41 \pm$ & $85.00 \pm$ \\
\hline & $6.17^{b}$ & $0.42^{d}$ & $0.85^{\mathrm{bc}}$ & $1.46^{d}$ & $0.70^{c}$ & $0.64^{b}$ \\
\hline \multirow[t]{2}{*}{$\mathrm{BPO}_{10}$} & $91.89 \pm$ & $2.31 \pm$ & $37.00 \pm$ & $52.61 \pm$ & $39.28 \pm$ & $83.33 \pm$ \\
\hline & $8.12^{b}$ & $0.33^{c}$ & $2.52^{\mathrm{b}}$ & $1.91^{\mathrm{cd}}$ & $2.62^{b c}$ & $3.47^{b}$ \\
\hline \multirow[t]{2}{*}{$\mathrm{BPO}_{15}$} & $75.03 \pm$ & $0.46 \pm$ & $42.62 \pm$ & $38.13 \pm$ & $36.90 \pm$ & $74.67 \pm$ \\
\hline & $2.88^{a}$ & $0.36^{a}$ & $2.81^{a}$ & $0.43^{b}$ & $2.87^{\mathrm{ab}}$ & $1.63^{a}$ \\
\hline \multirow[t]{2}{*}{$\mathrm{BPO}_{20}$} & $66.53 \pm$ & $0.48 \pm$ & $42.26 \pm$ & $31.29 \pm$ & $35.24 \pm$ & $72.21 \pm$ \\
\hline & $1.13^{a}$ & $0.67^{a}$ & $2.27^{\mathrm{a}}$ & $0.73^{a}$ & $2.31^{a}$ & $1.78^{a}$ \\
\hline
\end{tabular}

Values presented correspond to mean and standard deviations on a dry basis. a,b,c,d Different superscript letters indicate a statistical difference in mean values of the same column $(p \leq 0.05)$.

CB: control bread, $0 \%$ POP; $\mathrm{BPO}_{5}$ : bread with $5 \%$ of $\mathrm{POP}$; $\mathrm{BPO}_{10}$ : bread with $10 \%$ of POP; $\mathrm{BPO}_{15}$ : bread with $15 \%$ of POP; $\mathrm{BPO}_{20}$ : bread with $20 \%$ of $\mathrm{POP}$ 


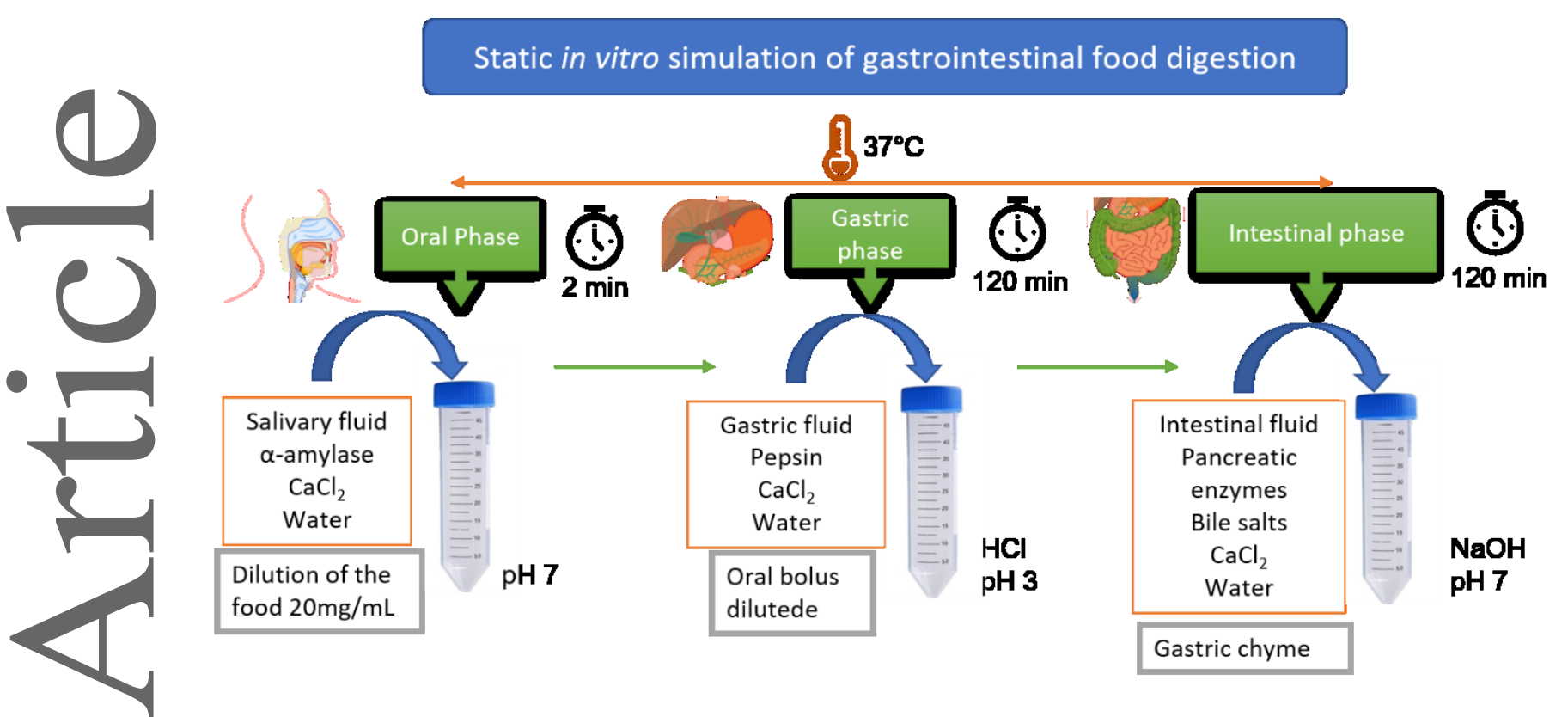

Figure 1. Diagram of the static in vitro digestion procedure. Adapted from Minekus et al., 2014.

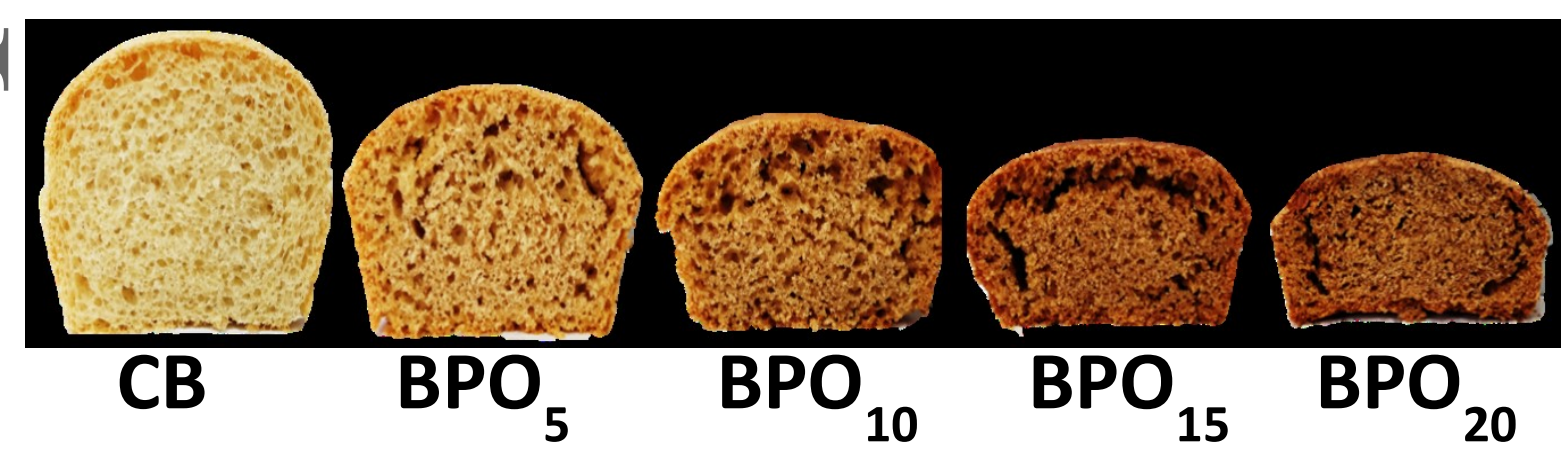

Figure 2. Images of cross section of bread enriched with Pleurotus ostreatus powder (POP). CB: control bread, $0 \%$ POP; $\mathrm{BPO}_{5}$ : bread with $5 \%$ of POP; $\mathrm{BPO}_{10}$ : bread with $10 \%$ of POP; $\mathrm{BPO}_{15}$ : bread with $15 \%$ of POP; $\mathrm{BPO}_{20}$ : bread with $20 \%$ of POP. 


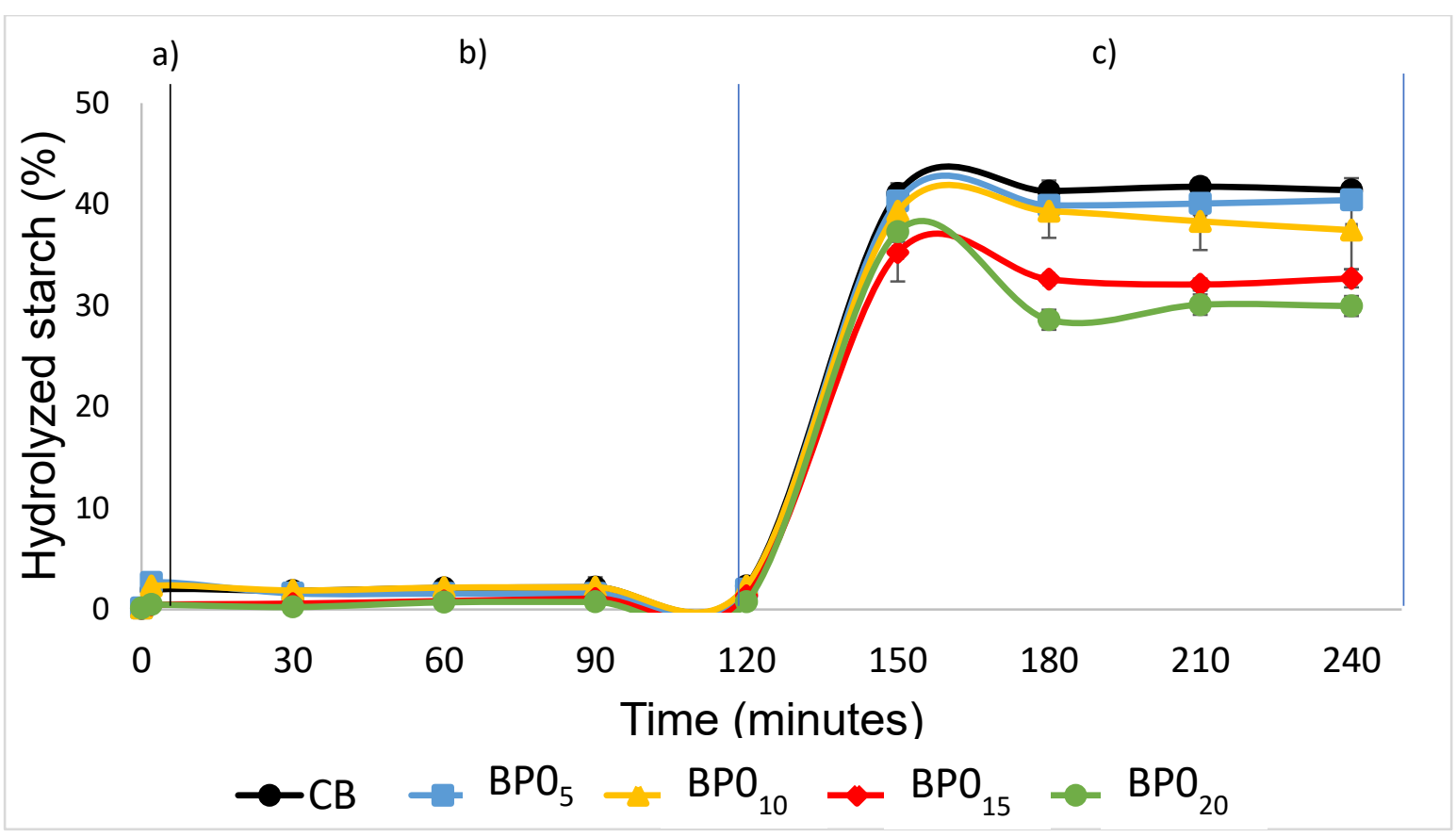

Figure 3. Hydrolyzed starch (\%) during in vitro starch digestion of bread enriched with Pleurotus ostreatus powder (POP). CB: control bread, 0\% POP; $\mathrm{BPO}_{5}$ : bread with $5 \%$ of $\mathrm{POP}$; $\mathrm{BPO}_{10}$ : bread with $10 \%$ of $\mathrm{POP}$; $\mathrm{BPO}_{15}$ : bread with $15 \%$ of $\mathrm{POP}$; $\mathrm{BPO}_{20}$ : bread with $20 \%$ of POP.

Error bars indicate the mean values \pm standard deviation.

a) Oral stage; b) gastric phase: c) intestinal phase. 


\section{Graphical Abstract}

In this work, new wheat bread formulations were developed by replacing wheat flour with different concentrations of an edible mushroom, Pleurotus ostreatus powder (PPO), with the aim of increasing its nutritional value and reducing its glycemic index. These findings suggest that the mushroom powder could be used as an alternative food ingredient to improve nutritional quality and reduce the glycemic index of bread.

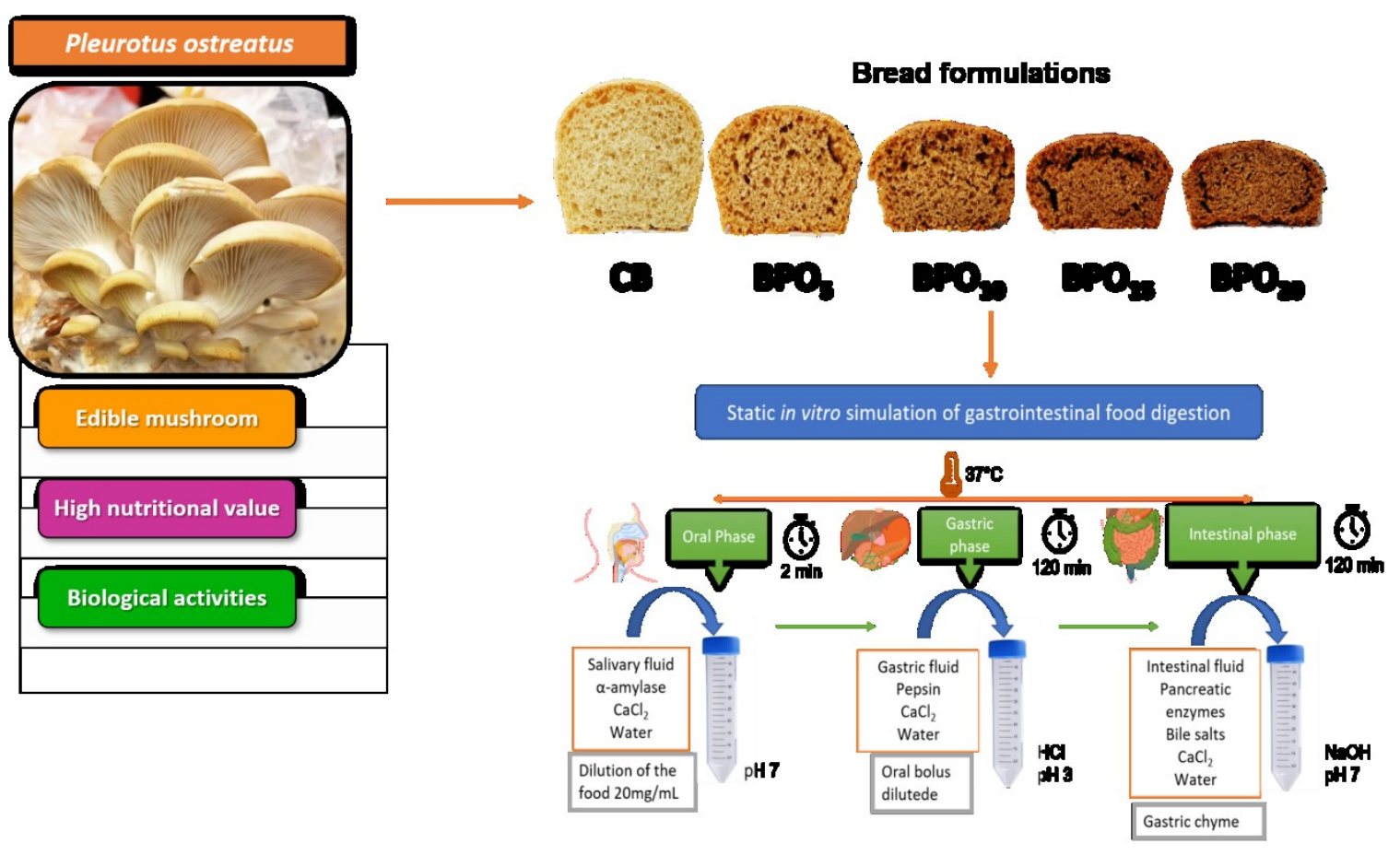

